\title{
Electrical and Exergy Analysis of a Simple Pass Photovoltaic-Thermal (PV/T) Air Heater with Slats Under Weather Conditions of the Far Nord Region, Cameroon
}

\author{
Paiguy Armand Ngouateu Wouagfack ${ }^{1, *}$, Ariane Laurelle Ngankou ${ }^{2}$, Noël Djongyang ${ }^{3}$, \\ Réné Tchinda ${ }^{4}$ \\ ${ }^{1}$ Department of Renewable Energy, Higher Technical Teachers' Training College, University of Buea, Kumba, Cameroon \\ ${ }^{2}$ Department of Physics, Faculty of Science, University of Yaoundé 1, Yaoundé, Cameroon \\ ${ }^{3}$ Department of Renewable Energy, National Advanced School of Engineering, University of Maroua, Sahel, Cameroon \\ ${ }^{4}$ University Institute of Technology Fotso Victor, University of Dschang, Bandjoun, Cameroon
}

Email address:

ngouateupaiguy@yahoo.fr (P. A. N. Wouagfack)

${ }^{*}$ Corresponding author

\section{To cite this article:}

Paiguy Armand Ngouateu Wouagfack, Ariane Laurelle Ngankou, Noël Djongyang, Réné Tchinda. Electrical and Exergy Analysis of a Simple Pass Photovoltaic-Thermal (PV/T) Air Heater with Slats Under Weather Conditions of the Far Nord Region, Cameroon. Advances in Applied Sciences. Vol. 4, No. 2, 2019, pp. 33-43. doi: 10.11648/j.aas.20190402.12

Received: March 23, 2019; Accepted: April 23, 2019; Published: May 26, 2019

\begin{abstract}
In this paper, a simple pass photovoltaic-thermal air heater system with slats has been considered to study its electrical and exergy performance by theoretical and numerical analysis. The collector has been modeled in such a way that the absorber plate is totally covered by photovoltaic modules. The climatic data (solar irradiation, ambient temperature) of the Far Nord region of Cameroon have been used. Thin metallic strips called slats have been attached longitudinally at the bottom side of the absorber plate of the system. The first and second laws of thermodynamics have been applied to write the equations describing the functioning of the system. These equations have been solved by numerical computation using the gradient conjugate method. The influences of some operating parameters on the electrical and overall exergy efficiencies were investigated. It was found that (i) it is of great importance to use slats as an integral part of the absorber surface in order to achieve better efficiencies of single pass photovoltaic-thermal systems and (ii) the instantaneous overall electrical and overall exergy efficiencies of a simple pass hybrid (PV/T) solar air heater varies between $9-12 \%$ and $11,5-18,5 \%$ respectively.
\end{abstract}

Keywords: Simple Pass, Exergy, Hybrid Photovoltaic Thermal, Solar Air Heater, Slats, Electrical Energy

\section{Introduction}

Renewable energies are going to be a main substitute for fossil fuels in the coming years for their clean and renewable nature. Solar energy is one of the most significant renewable energy sources that world needs. The major applications of solar energy can be classified into two categories: solar thermal energy systems convert solar energy into heat and solar photovoltaic systems convert solar energy into electrical energy. Usually, these systems are used separately. In the solar thermal system, external electrical energy is required to circulate the working fluid through the system. On the other hand, in the PV system, the electrical efficiency of the system decreases rapidly as the PV module temperature increases. Therefore, in order to achieve higher electrical efficiency, the PV module should be cooled by removing the heat in some way. In order to eliminate an external electrical source and to cool de PV module, the PV module should be combined with the solar air/water heater collector. This type of system is called solar photovoltaic thermal (PV/T) collector. A hybrid PV/T collector produces both thermal and electrical energy simultaneously. This concept increases the electrical efficiency of photovoltaic systems 
by increasing cooling rate and overall efficiency of the hybrid unit. The advantage of the PV/T collector system lies in the reduction of the demands on physical space and the equipment cost through the use of common frame and brackets as compared to the separated PV and solar thermal systems placed side-by-side. The performance of a $\mathrm{PV} / \mathrm{T}$ air collector parametrically depends on climatic, operating and design parameters such as ambient temperature, solar radiation intensity, wind speed, solar cell temperature, back surface temperature, inlet and outlet air temperature, inlet air velocity, overall heat transfer coefficient, etc. It can be evaluated in terms of the first and second laws of thermodynamics. Its evaluation based on the first and second laws of thermodynamics is known as energy efficiency and exergy efficiency, respectively. A number of theoretical, numerical and experimental studies have been reported particularly during the last decade about the solar hybrid PV/T collector using air or water or both as working fluid. Kern and Russell [1] have first put forth the concept of integrated $\mathrm{PV} / \mathrm{T}$ collector based energy system. Fujisawa and Tani [2] compared the annual performance of a flat-plate solar-water-heating collector, a PV module, a single-glazed $\mathrm{PV} / \mathrm{T}$ collector with monocrystalline silicon solar cells, and an unglazed one. Chow et al [3] evaluated the use of glass cover at the PV/T collector system from the thermodynamic point of view. Bosanac et al. [4] carried out exergy analysis of a PV/T system. Saitoh et al. [5] compared the energy and exergy efficiencies of a brine-cooled PV/T collector with a PV panel and a solar collector in northern Japan. The monthly energy efficiency and exergy efficiency of PV/T system for Indian climates were detailed by Joshi and Tiwari [6]. Dubey and Tiwari [7] evaluated the overall thermal energy and exergy provided in the form of heat and electricity from hybrid photovoltaic thermal (PV/T) solar water heating system considering five different cases with and without withdrawal and found that annual maximum heat and electricity is obtained in the case of continuous withdrawal. Dubey et al [8] carried out the energetic and exergetic performance analysis of $\mathrm{PV} / \mathrm{T}$ air collectors connected in series with air duct above and below the absorber plate for four weather conditions of five different cities of India. It has been found that the $\mathrm{PV} / \mathrm{T}$ air collector with air duct below the absorber plate gives better results in terms of thermal energy, electrical energy and exergy gain in comparison to the air duct above the absorber plate. Agrawal and Tiwari [9] performed experiments on a building integrated photovoltaic thermal (BIPVT) system fitted on the rooftop of an experimental laboratory for analyzing the energy, exergy and electrical energy under different weather conditions. Nayak and Tiwari [10] studied the yearly effectiveness of PV/T collector and earth air heat exchanger (EAHE) integrated with a greenhouse in terms of the energy and exergy analysis. They [11] presented the performance of a PV/T integrated greenhouse system for New Delhi climatic conditions. Sarhaddi et al [12] assessed the exergetic performance of a solar photovoltaic thermal (PV/T) air collector. Tiwari et al [13] introduced an analytical expression for the water temperature of the integrated $\mathrm{PV} / \mathrm{T}$ solar water heater under constant flow rate. Raman and Tiwari [14] made comparative study on energy and exergy performance of a hybrid photovoltaic double pass and single pass air collector by using opaque PV module. It has been observed that electrical, thermal and exergy efficiency of double-pass hybrid $\mathrm{PV} / \mathrm{T}$ air collector are higher than that of single. Deepali Kamthania et al [15] analyzed the performance of a hybrid PV/T double pass façade for space heating for the composite climate of New Delhi by using semi transparent PV module. Assoa et al. [16] developed mathematical model of a PV/T dual fluid collector with metal absorber. Srinivas and Jayaraj [17] conducted work on the analytical and experimental performance of a hybrid PV/T double pass with slats. It has been concluded that the metals slats improve the system performance by increasing the cooling rate of the absorber plate. Srinivas and Jayaraj [18] studied experimentally energetic and exergetic analysis of a hybrid PV/T double pass with slats air heater. Othman et al. [19] studied experimentally the electrical and thermal efficiencies of a conventional double pass photovoltaic/thermal PV/T solar collector integrated with both water and air heating system. Jarimi et al. [20] conducted theoretical and indoor experimental analysies of a bi-fluid type photovoltaic/thermal PV/T solar collector for steady-state analysis under the solar simulator at Solar Energy Research Lab UiTM Perlis, Malaysia. Bakar et al. [21] showed through simulation that when both air and water are operated simultaneously the overall thermal and electrical performance of the photovoltaic/thermal (PV/T) solar collector is higher than when both fluids are operated independently. Ahmed and Mohammed [22] studied the effect of the dust on the performance of hybrid photovoltaic/thermal PV/T solar collector. They [23] proposed a simulation model to predict the electrical and thermal performance of a hybrid photovoltaic/thermal $\mathrm{PV} / \mathrm{T}$ solar collector. Sobhnamayan et al. [24] carried out the optimization of a solar photovoltaic thermal $(\mathrm{PV} / \mathrm{T})$ water collector on the basis of the exergy concept. Jee Joe et al. [25] gave a brief overview of the different solar flat plate $\mathrm{PV} / \mathrm{T}$ technologies, their efficiencies, applications, advantages, limitations and research opportunities available.

In the present work the exergetic and electrical performance of a simple pass hybrid (PV/T) solar air heater with slats (SPHSAH) was studied for Far Nord region of Cameroon. It is expected that the provision of slats will improve the cooling rate and there by SPHSAH overall performance. Mono-crystalline silicon solar cells were used in the present device. A computer simulation program that uses an iterative solution procedure was developed to predict the electrical and exergetic efficiency of the hybrid system. 


\section{Analysis}

The simple pass hybrid photovoltaic thermal (PV/T) solar air heater consisted of aluminum absorber plate. Its length is $\mathrm{L}_{\mathrm{c}}=6 \mathrm{~m}$, its total width is $\mathrm{W}=1 \mathrm{~m}$ and its thickness is $2 \mathrm{~mm}$. The sides and bottom of the collector were insulated with a $5 \mathrm{~cm}$ thick layer of cork. The depth of the upper and lower channels was $25 \mathrm{~mm}$ (each). Twenty slats of size $25 \mathrm{~mm}$ depth, $6 \mathrm{~m}$ long and thickness of $2 \mathrm{~mm}$ (each) were fixed longitudinally at equal distance at the bottom side of the absorber plate. A glass of dimensions $1 \mathrm{~m} \times 6 \mathrm{~m}(\mathrm{~W} \times \mathrm{L})$ and thickness $2 \mathrm{~mm}$ was provided as front cover for reducing convection heat losses from the collector. The surface of absorber is cover entirely by the PV modules (mono-crystalline silicone solar cells). The simple pass $\mathrm{PV} / \mathrm{T}$ air collector with slats is shown schematically in Figure 1. The heat balance equations for this design are obtained from the thermal network at the cover, absorber plate, bottom plate, metal slats and airflow as indicated in Figure 2.

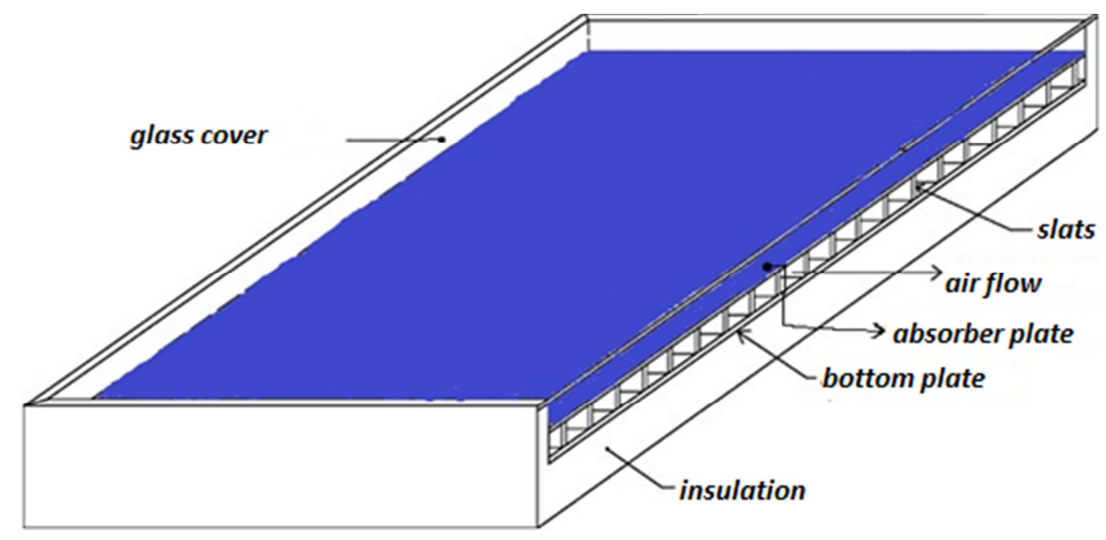

Figure 1. Simple pass hybrid photovoltaic thermal $(P V / T)$ solar air heater with slats.

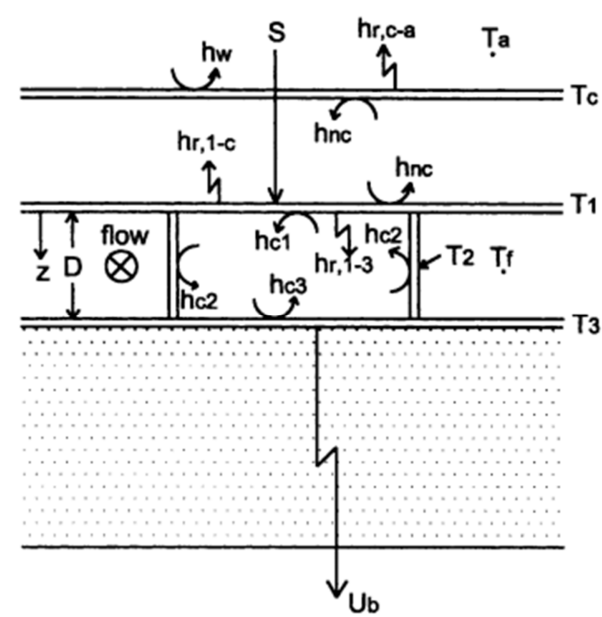

Figure 2. Physical model of simple pass hybrid photovoltaic thermal (PV/T) air heater with slats.

A steady state one dimensional analysis is done on the system. To simplify the analysis following assumptions were made.

1. The system is in quasi - steady state
2. The temperature gradient across the flow direction is negligible

3. Good contact between the slats and the plates

4. One dimensional heat conduction is good approximation for the present study

5. Temperature of the glass cover, absorber plate and bottom plate vary only in the air flow direction.

\subsection{Energy Balance Equations}

The energy balance equations are written for various segments of the PV/T hybrid air heater with slats as given below.

(i). Glass cover

$$
S_{1}+U_{t}\left(T_{1}-T_{c}\right)=h_{w}\left(T_{c}-T_{a}\right)+h_{r c a}\left(T_{c}-T_{a}\right)
$$

where, $S_{1}=I(t) \alpha_{c}$ and $U_{t}=h_{r 1 c}+h_{n c}$

(ii). Absorber plate

$$
U_{t}\left(T_{1}-T_{c}\right)+h_{c 1}\left(T_{1}-T_{f}\right)+h_{r 13}\left(T_{1}-T_{3}\right)+\eta_{e l} \beta S_{2}+\frac{1}{A_{c}}\left(-k A n \frac{d T_{2}}{d z}\right)_{z=0}=\alpha_{p v} \beta S_{2}
$$

where, $S_{2}=I(t)\left(\tau_{c} \alpha_{c}\right)_{e}$

(iii). Bottom plate

$$
h_{r 13}\left(T_{1}-T_{3}\right)+\frac{1}{A_{c}}\left(-k_{s} A n \frac{d T_{2}}{d z}\right)_{z=D}=h_{c 3}\left(T_{3}-T_{f}\right)+U_{b}\left(T_{3}-T_{a}\right)
$$


(iv). Metal slat

$$
\left(-k_{s} A \frac{d T_{2}}{d z}\right)_{z=0}-\left(-k_{s} A \frac{d T_{2}}{d z}\right)_{z=D}=\frac{1}{A_{c}} \int_{z=0}^{z=D} 2 h_{c 2} L_{c}\left(T_{2}-T_{f}\right) d z
$$

(v). Air flow

$$
h_{c 1}\left(T_{1}-T_{f}\right)+h_{c 3}\left(T_{3}-T_{f}\right)+\frac{1}{A_{c}} \int_{z=0}^{z=D} 2 h_{c 2} n L_{c}\left(T_{2}-T_{f}\right) d z=q_{u}
$$

\subsection{Analytical Solution}

The expressions for the conduction heat transfer when $\mathrm{z}=0$ and $\mathrm{z}=\mathrm{D}$ are obtained by applying the energy conservation equation over an element of the metal slat of depth $\Delta z$ as shown in Figure 3 (a). This is considered as a classical fin case,

$$
\left(-k_{s} A \frac{d T_{2}}{d Z}\right)_{z}-\left(-k_{s} A \frac{d T_{2}}{d Z}\right)_{z+d z}=2 h_{c 2} L_{c} \Delta Z\left(T_{2}-T_{f}\right)
$$

Dividing through by, $\Delta \mathrm{z}$, and finding the limit as $\Delta \mathrm{z}$ approaches zero yields,

$$
\frac{d^{2} T_{2}}{d z^{2}}-\frac{2 L_{c} h_{c 2}}{k_{s} A}\left(T_{2}-T_{f}\right)=0
$$

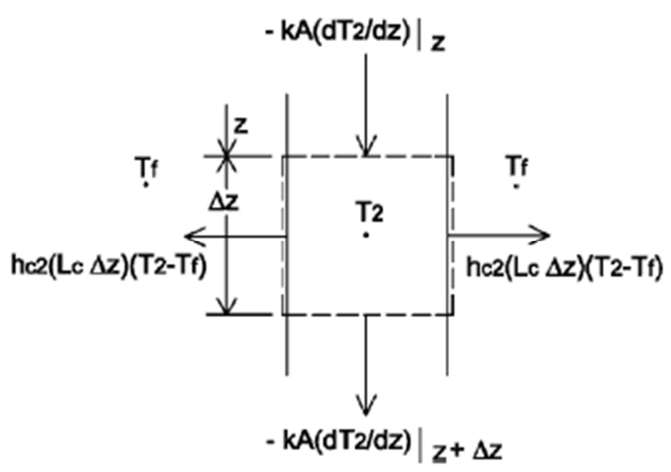

(a)

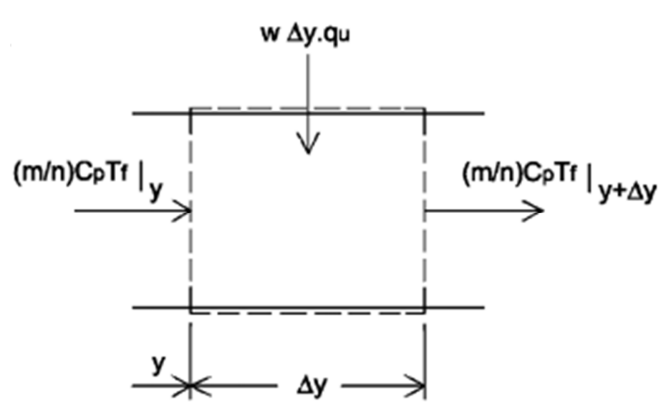

(b)

Figure 3. Energy balance on (a) element along slat depth, and (b) element along flow direction [27].

$$
\text { Let } m^{2}=\frac{2 L_{c} h_{c 2}}{k_{s} A} \text { and } \theta=T_{2}-T_{f} \text { hence }
$$

$$
\frac{d^{2} \theta}{d z^{2}}-m^{2} \theta=0
$$

The general solution of the ordinary differential equation (7) is,

$$
\theta=a_{1} e^{-m Z}+a_{2} e^{m Z}
$$

where $a_{1}$ and $a_{2}$ are arbitrary constants whose values are determined by the following boundary conditions, $\theta_{z=0}=T_{1}-T_{f}=\theta_{1}$ et $\theta_{z=D}=T_{3}-T_{f}=\theta_{3}$

Substituting the boundary conditions into the general solution and solving, we obtain

$$
a_{1}=\frac{\theta_{1} e^{m D}-\theta_{3}}{e^{m D}-e^{-m D}} \text { and } a_{2}=\frac{\theta_{3}-\theta_{1} e^{-m D}}{e^{m D}-e^{-m D}} .
$$

The general solution then becomes,

$$
\theta=\frac{\theta_{1}\left[e^{m(D-Z)}-e^{-m(D-Z)}\right]+\theta_{3}\left(e^{m Z}-e^{-m Z}\right)}{e^{m D}-e^{-m D}}
$$

Therefore

$$
\begin{gathered}
\theta=\frac{\theta_{1} \operatorname{Sinh}[m(D-Z)]+\theta_{3} \operatorname{Sinh}(m Z)}{\operatorname{Sinh}(m D)} \\
\frac{d \theta}{d Z}=\frac{-m \theta_{1} \operatorname{Cosh}[m(D-Z)]+m \theta_{3} \operatorname{Cosh}(m Z)}{\operatorname{Sinh}(m D)}
\end{gathered}
$$

Hence the conduction expression when $\mathrm{Z}=0$ and $\mathrm{Z}=\mathrm{D}$ become,

$$
\begin{gathered}
\left(-k_{s} A n \frac{d \theta}{d Z}\right)_{Z=0}=\frac{m k_{s} A n\left[\theta_{1} \operatorname{Cosh}(m D)-\theta_{3}\right]}{\operatorname{Sinh}(m D)} \\
\left(-k_{s} A n \frac{d \theta}{d Z}\right)_{Z=D}=\frac{m k_{s} A n\left[\theta_{1}-\theta_{3} \operatorname{Cosh}(m D)\right]}{\operatorname{Sinh}(m D)}
\end{gathered}
$$

And since $m=\sqrt{2 h_{c 2} L_{c} / k_{s} A}$, let, $C=\frac{\sqrt{2 h_{c 2} L_{c} k_{s} A n^{2}}}{\operatorname{Sinh}(m D)}$ Hence,

$$
\begin{aligned}
& \left(-k_{s} A n \frac{d \theta}{d Z}\right)_{Z=0}=C\left[\theta_{3}-\theta_{1} \operatorname{Cosh}(m D)\right] \\
& \left(-k_{s} A n \frac{d \theta}{d Z}\right)_{Z=D}=C\left[\theta_{3} \operatorname{Cosh}(m D)-\theta_{1}\right]
\end{aligned}
$$


Substituting equation (12) into equation (2) and letting $F_{1}=\frac{C}{A_{c}}$ we have,

$$
\begin{gathered}
T_{1}=\frac{1}{U_{t}+h_{c 1}+h_{r 13}-F_{1} \operatorname{Cosh}(m D)}\left[\left(h_{r 13}-F_{1}\right) T_{3}+\left(h_{c 1}-F_{1} \operatorname{Cosh}(m D)+F_{1}\right) T_{f}+U_{t} T_{c}+\left(\alpha_{p v}-\eta_{e l}\right) S_{2} \beta\right] \text { And letting } \\
F_{2}=U_{t}+h_{c 1}+h_{r 13}-F_{1} \operatorname{Cosh}(m D) \text { and } F_{3}=h_{r 13}-F_{1} \text { we have, } \\
T_{1}=\frac{1}{F_{2}}\left[F_{3} T_{3}+\left(h_{c 1}-F_{1} \operatorname{Cosh}(m D)+F_{1}\right) T_{f}+U_{t} T_{c}+\left(\alpha_{p v}-\eta_{e l}\right) S_{2} \beta\right]
\end{gathered}
$$

And subtracting $\mathrm{T}_{\mathrm{f}}$ from both sides of equation (14) and regrouping results,

$$
\begin{gathered}
T_{1}-T_{f}=\frac{F_{3} T_{3}+\left(h_{c 1}-F_{1} \operatorname{Cosh}(m D)+F_{1}\right) T_{f}+U_{t} T_{c}+\left(\alpha_{p v}-\eta_{e l}\right) S_{2} \beta-F_{2} T_{f}}{F_{2}} \\
T_{1}-T_{f}=\frac{1}{F_{2}}\left[F_{3}\left(T_{3}-T_{f}\right)+U_{t}\left(T_{c}-T_{f}\right)+\left(\alpha_{p v}-\eta_{e l}\right) S_{2} \beta\right]
\end{gathered}
$$

Similarly, by substituting equation (13) into equation (3) and rearranging results,

$$
T_{3}=\frac{1}{h_{c 3}+h_{r 13}+U_{b}-F_{1} \operatorname{Cosh}(m D)}\left[F_{3} T_{1}+\left(h_{c 3}-F_{1} \operatorname{Cosh}(m D)+F_{1}\right) T_{f}+U_{b} T_{a}\right]
$$

Let $F_{4}=h_{c 3}+h_{r 13}+U_{b}-F_{1} \operatorname{Cosh}(m D)$ then we have,

$$
T_{3}=\frac{1}{F_{4}}\left[F_{3} T_{1}+\left(h_{c 3}-F_{1} \operatorname{Cosh}(m D)+F_{1}\right) T_{f}+U_{b} T_{a}\right]
$$

and subtracting $\mathrm{T}_{\mathrm{f}}$ from both sides of equation (16) and regrouping results,

$$
T_{3}-T_{f}=\frac{1}{F_{4}}\left[F_{3}\left(T_{1}-T_{f}\right)+U_{b}\left(T_{a}-T_{f}\right)\right]
$$

Solving equation (15) and (17) for $T_{1}-T_{f}$ and $T_{3}-T_{f}$, we obtain,

$$
\begin{aligned}
& T_{1}-T_{f}=\left(\frac{F_{3} U_{b}+U_{t} F_{4}}{F_{3}^{2}-F_{2} F_{4}}\right)\left(T_{f}-T_{a}\right)-\left(\frac{F_{4}}{F_{3}^{2}-F_{2} F_{4}}\right)\left(U_{t}\left(T_{c}-T_{f}\right)+\left(\alpha_{p v}-\eta_{e l}\right) S_{2} \beta\right) \\
& T_{3}-T_{f}=\left(\frac{F_{3} U_{t}+U_{b} F_{2}}{F_{3}^{2}-F_{2} F_{4}}\right)\left(T_{f}-T_{a}\right)-\left(\frac{F_{3}}{F_{3}^{2}-F_{2} F_{4}}\right)\left(U_{t}\left(T_{c}-T_{f}\right)+\left(\alpha_{p v}-\eta_{e l}\right) S_{2} \beta\right)
\end{aligned}
$$
$T_{3}$,

Now, substituting equation (4) into equation (5) to represent the useful heat gain by the circulated air flow in terms of $T_{l}$ and

$$
q_{u}=\left(h_{c 1}-F_{1} \operatorname{Cosh}(m D)+F_{1}\right)\left(T_{1}-T_{f}\right)+\left(h_{c 3}-F_{1} \operatorname{Cosh}(m D)+F_{1}\right)\left(T_{3}-T_{f}\right)
$$

and letting $F_{5}=h_{c 1}-F_{1} \operatorname{Cosh}(m D)+F_{1}$ and $F_{6}=h_{c 3}-F_{1} \operatorname{Cosh}(m D)+F_{1}$, hence,

$$
q_{u}=F_{5}\left(T_{1}-T_{f}\right)+F_{6}\left(T_{3}-T_{f}\right)
$$

\subsection{Temperature Distribution Along Flow Direction}

Consider the heat flows into and out of an element of thickness $\Delta y$ in a single air stream at a distance $y$ from the entrance of a collector as shown in Figure 3(b). The temperatures of the walls of the duct forming the air channel are assumed uniform but no equal to each other for each wall. The temperature of the air stream at a distance $y$ from the 
collector inlet is assumed to be at $T_{f i}$ and it increases until it reaches $T_{f o}$ at the exit. The air temperature is assumed uniform at $T_{f}$ throughout the cross section. The balance on the air flowing through the element can be expressed as follows,

$$
\left(\frac{\dot{m}}{n}\right)\left(C_{p} T_{f}\right)_{y}+w \Delta y q_{u}=\left(\frac{\dot{m}}{n}\right)\left(C_{p} T_{f}\right)_{y+\Delta y}
$$

where $m$ is the total mass flow rate through the collector and $\mathrm{n}$ here is the number of air channels.

Dividing through by, $\Delta y$, and finding the limit as $\Delta y$ approaches zero yields,

$$
\frac{d T_{f}}{d y}=\frac{n w q_{u}}{m C_{p}}
$$

By assuming that the useful heat transferred to the air is uniform along a collector of length $\mathrm{L}$, the mean air temperature at the outlet can be found by integrating the above equation to give

$$
T_{f o}-T_{f i}=\frac{A_{c} q_{u}}{\dot{m} C_{p}}
$$

This assumption implies that the air temperature varies linearly along the collector. This assumption is valid for short collectors [26]. The mean air temperature is then equal to arithmetic mean $\mathrm{T}_{\mathrm{f}}=\left(\mathrm{T}_{\mathrm{fi}}+\mathrm{T}_{\mathrm{fo}}\right) / 2$

The useful heat transferred to the moving air stream can then be written in terms of the mean fluid and inlet temperature as

$$
q_{u}=\frac{\dot{m} C_{p}}{A_{c}}\left(T_{f o}-T_{f i}\right)=\frac{\dot{2 m} C_{p}}{A_{c}}\left(T_{f}-T_{f i}\right)
$$

\subsection{Mean Temperatures Matrices}

Rearranging the equations (1) and (14) we obtain,

$$
\begin{aligned}
& \left(U_{t}+h_{r c a}+h_{w}\right) T_{c}-U_{t} T_{1}+0 T_{f}+0 T_{3}=\left(h_{r c a}+h_{w}\right) T_{a}+S_{1} \\
& -U_{t} T_{c}+F_{2} T_{1}-\left(F_{2}-U_{t}-F_{3}\right) T_{f}-F_{3} T_{3}=\left(\alpha_{p v}-\eta_{e l}\right) S_{2} \beta
\end{aligned}
$$

By substituting equation (4) into equation (5) we obtain,

$$
q_{u}=h_{c 1}\left(T_{1}-T_{f}\right)+h_{c 3}\left(T_{3}-T_{f}\right)+\frac{n}{A_{c}}\left(-k_{s} A \frac{d T_{2}}{d Z}\right)_{z=0}-\frac{n}{A_{c}}\left(-k_{s} A \frac{d T_{2}}{d Z}\right)_{z=D}
$$

By substituting equations (12), (13) and (23) into equation (27) and rearranging we obtain,

$$
0 T_{c}+F_{5} T_{1}-\left(h_{c 1}+h_{c 3}+2 F_{1}-2 F_{1} \operatorname{Cosh}(m D)+\gamma\right) T_{f}+F_{6} T_{3}=-\gamma T_{f i}
$$

where $\gamma=\frac{2 C_{p} \dot{m}}{A_{c}}$

Equation (16) gives,

$$
0 T_{c}-F_{3} T_{1}-\left(F_{4}-U_{b}-F_{3}\right) T_{f}+F_{4} T_{3}=U_{b} T_{a}
$$

In general, the above equations (25), (26), (28) and (29) may be displayed in a 4 x 4 matrix form:

$$
\left[\begin{array}{cccc}
-\left(U_{t}+h_{r c a}+h_{w}\right) & -U_{t} & 0 & 0 \\
-U_{t} & F_{2} & -\left(F_{2}-U_{t}-F_{3}\right) & -F_{3} \\
0 & F_{5} & -\left(h_{c 1}+h_{c 3}-2 F_{1} \cosh (m D)+2 F_{1}+\gamma\right) & F_{6} \\
0 & -F_{3} & -\left(F_{4}-U_{b}-F_{3}\right) & F_{4}
\end{array}\right]\left[\begin{array}{l}
T_{c} \\
T_{1} \\
T_{f} \\
T_{3}
\end{array}\right]=\left[\begin{array}{l}
\left(h_{r c a}+h_{w}\right) T_{a}+S_{1} \\
\left(\alpha_{p v}-\eta_{e l}\right) S_{2} \beta \\
-\gamma T_{f i} \\
U_{b} T_{a}
\end{array}\right]
$$

In general, the above matrices may be displayed as

$$
[A][T]=[B]
$$

The mean temperature vector may be determined numerically by Conjugate gradient matrix method using standard computer packages.

\subsection{Performance of System}

The instantaneous thermal efficiency of a simple pass hybrid $(\mathrm{PV} / \mathrm{T})$ solar air heater is expressed as

$$
\eta_{t h}=\frac{\dot{m} C_{p}\left(T_{f o}-T_{f i}\right)}{A_{c} I(t)}
$$

The electrical efficiency of system is expressed as

$$
\eta_{e l}=\eta_{e l, r e f}\left(1-0,0045\left(T_{1}-25.15\right)\right)
$$

where, $\eta_{\text {el,ref }}=0.12$ [12]. 
The overall exergy efficiency of a simple pass hybrid $(\mathrm{PV} / \mathrm{T})$ solar air heater is expressed as [12]

$$
\eta_{e x}=\eta_{t h}\left(1-\frac{T_{a}}{T_{f_{o}}}\right)+\eta_{e l}
$$

\section{Theoretical Solution Procedure}

The computer programme is based on FORTRAN 90. The theoretical model assumes that for a short collector, the temperatures of the walls surrounding the air stream are uniform and the temperature of the air streams vary linearly along the collector. A long collector can be assumed to be divided equally into a finite number of short collectors, or sections. The walls and mean temperatures of the first section are initially guessed and set equal to ambient temperature, except that of the absorber which was set to a temperature of $20^{\circ} \mathrm{C}$ above that of the ambient temperature [27]. The heat transfer coefficients are computed accordingly to the initially guessed temperature values. An iterative process is then created and the mean temperatures for the section calculated using the Conjugate gradient method. The newly computed temperatures are then compared with the previously assumed ones, and the process is repeated until all consecutive mean temperatures differ by less than $0.01^{\circ} \mathrm{C}$. Consider the next section, the mean wall and air temperatures are set equal to those of the previous section. The inlet air temperature of the second section is set equal to the outlet air temperatures of the first section. The iterative procedure is repeated until all the sections of the given collector are considered, and all the time was for $12 \mathrm{~h}$ from sunrise to sunset, that is from $6 \mathrm{~h} 30$ a.m to $6 \mathrm{~h} 30$ p.m. By this procedure, wall and mean air temperatures can be predicted for the complete length of collector. At the end iteration, the programme calculates the outlet temperature and also the electrical and exergy efficiency. The flowchart is shown in Figure 4.

The major values of parameters used were as follows,

1. Number of sections along the collector $=60$

2. Length of collector $=6 \mathrm{~m}$

3. Width of collector $=1 \mathrm{~m}$

4. Spacing between successive slats, $\mathrm{w}=0,05 \mathrm{~m}$

5. Thickness of insulation $=0,05 \mathrm{~m}$

6. Wind speed, $\mathrm{Vw}_{\mathrm{w}}=2 \mathrm{~m} / \mathrm{s}$

7. Prandtl number, $\operatorname{Pr}=0,70$

8. Thermal conductivity of insulation material $=0,045 \mathrm{~W} / \mathrm{m} . \mathrm{K}$

9. Thermal conductivity of slats material $=204 \mathrm{~W} / \mathrm{m} . \mathrm{K}$

10. Emittance of bottom plate selective surface $\varepsilon_{3}=0,1$

11. Emittance of absorber plate selective surface $\varepsilon_{1}=0,1$

12. Emittance of glass cover, $\mathcal{E}_{c}=0,88$

13. Effective transmittance-absorptance product, $(\tau \alpha)_{e}$ $=0,82$

14. The inclinaison of collector $=30 \mathrm{o}$

\section{Result and Discussion}

The effect of various parameters on the electrical and exergy performance of the present air heater was investigated. The slats do increase the exposed area of heat transfer to the air flow, and increase the average temperature of the insulated bottom plate through conduction mode transfer, and simultaneously decrease the temperature of the absorber plate that is associated with a decrease in the top heat losses and a increase in the electrical and exergy performance.

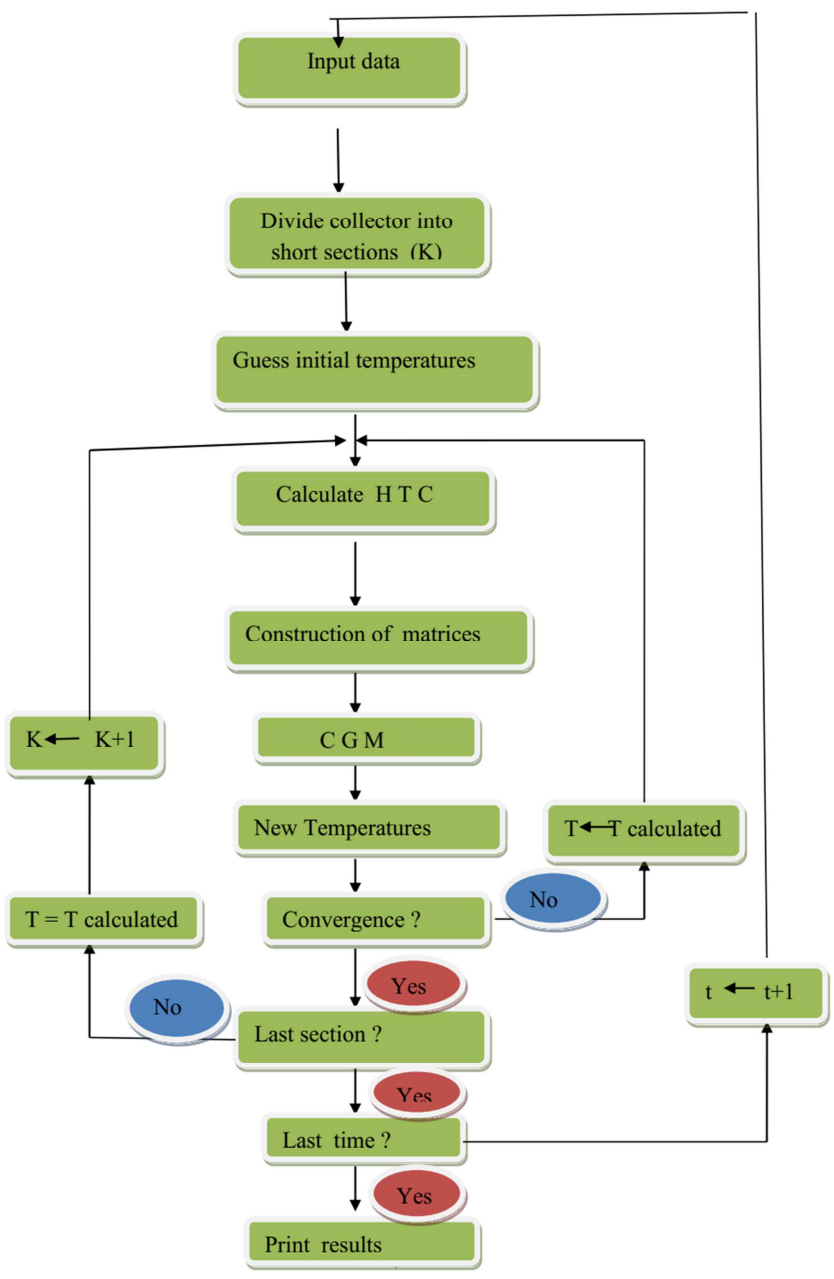

Figure 4. Flowchart for computer programme.

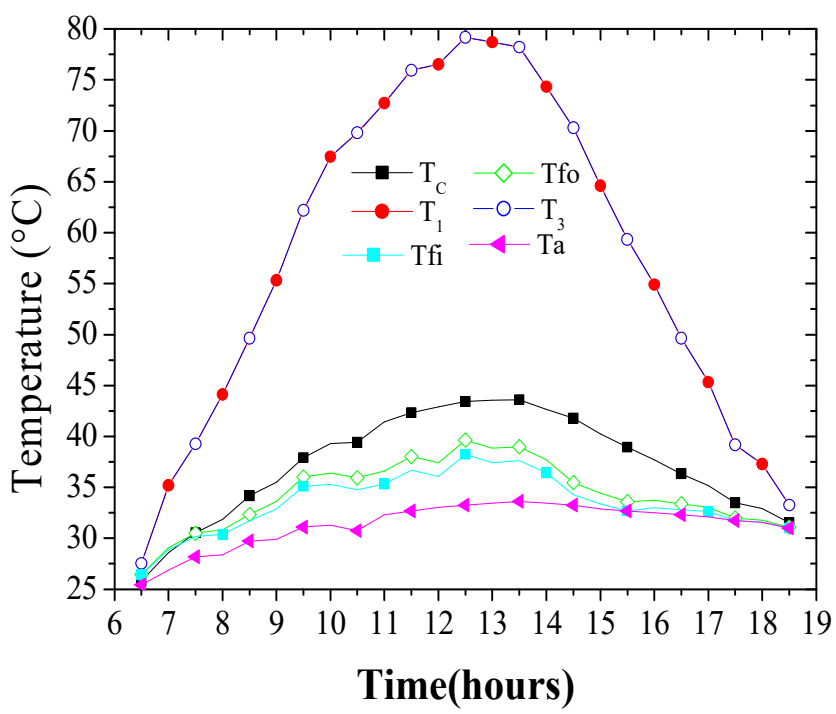

Figure 5. Hourly variation of various temperatures. 


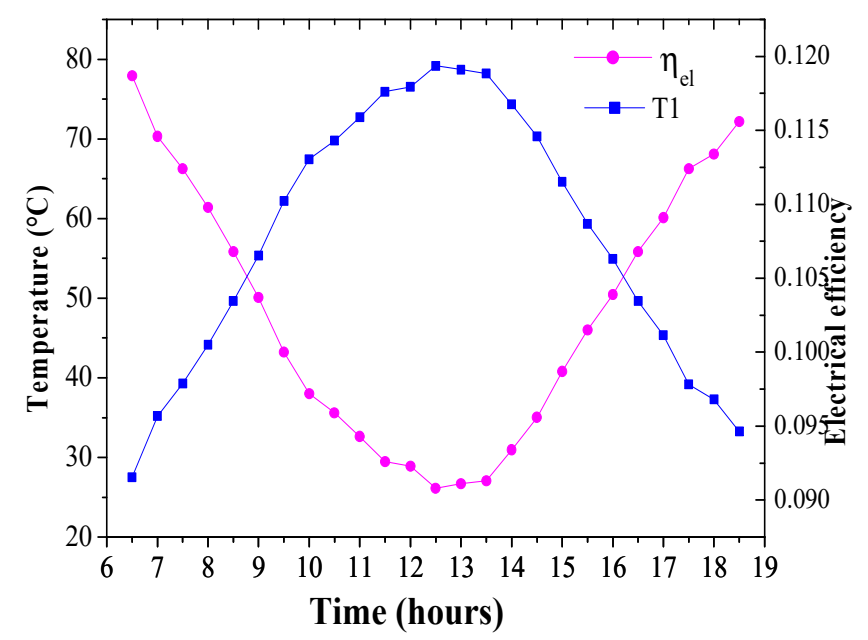

Figure 6. Hourly variation of solar cell temperature and electrical efficiency.

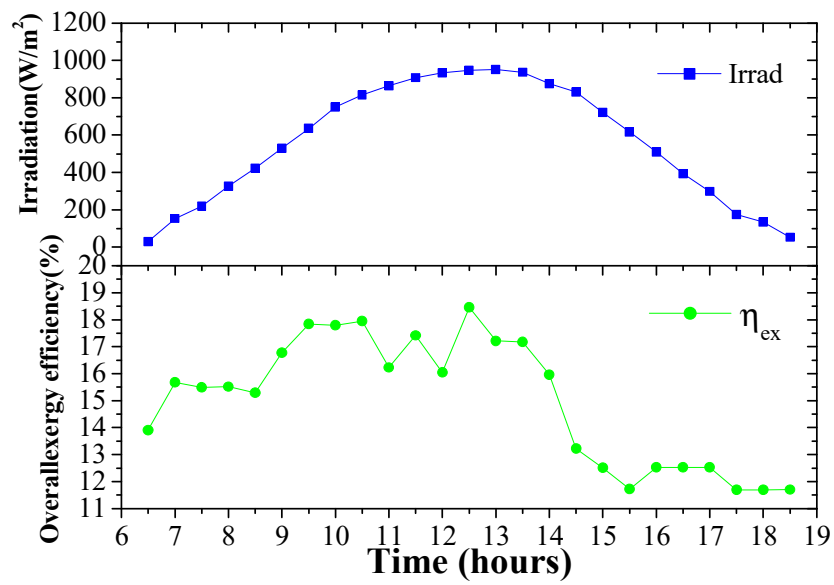

Figure 7. Hourly variation of solar irradiation and overall exergy efficiency.

Figure 5 shows the hourly variation of various temperatures. It is observed that solar cell temperature $\left(\mathrm{T}_{1}\right)$ of simple pass hybrid (PV/T) solar air heater is always higher, through a conduction heat mode transfer of slats. The temperature of bottom insulated plate $\left(\mathrm{T}_{3}\right)$ also higher in comparison to temperature of glass cover $\left(\mathrm{T}_{\mathrm{C}}\right)$ due to the convective heat transfer with ambient. The ambient air, inlet air and collector outlet air temperatures are gradually increasing from sunrise to noon and decreasing from noon to sunset. Since air is flowing over absorber plate (PV panel), it gets heated up as indicated by the outlet air temperature which is always more than the ambient air temperature. Hourly variation of solar cell temperature and electrical efficiency is shown in Figure 6. It shows that with the increase in solar cell temperature, cell efficiency decreases and it becomes almost constant at constant cell temperature and at the end of the day it will again increase due to the decrease in cell temperature. Hourly variation of solar irradiation and exergy efficiency is shown in Figure 7. It can be seen that solar irradiation increases from sunrise to noon to attain the maximum value $\left(900 \mathrm{~W} / \mathrm{m}^{2}\right)$ at $12 \mathrm{~h} 30$ a.m and decrease to sunset and the exergy efficiency varies between $11,5 \%$ and $18,5 \%$. Its maximum value is obtained at $12 \mathrm{~h} 30$ a.m. Figure 8 shows that electrical efficiency of the system increases with the increase in air mass flow rate, meanwhile the exergy efficiency decreases. Air mass flow rate as it extracts heat which is collected by simple pass hybrid collector results in the decrease of the exergy efficiency of the system, providing the better cooling of the simple pass hybrid solar air heater, thus causing the better electrical performance of the system. Figure 9 shows that the effect of wind speed on the electrical and exergy efficiency has a similar behavior as that of air mass flow rate. The effect of the separation distance between absorber and bottom plates on the electrical and exergy efficiency of the system is illustrated in Figure 10, in which the distance was varied from $0.01-0.06 \mathrm{~m}$. It shows that the electrical efficiency is almost constant when the separation distance between absorber and bottom plates increases, meanwhile the exergy efficiency of the system increases. The variations of temperatures along the length are shown in Figure 11. The increase of temperatures of absorber plate, bottom plate and glass cover is noticeable after the air stream passes through the half meter of collector and they become almost constant. The outlet air temperature is constant along the length of collector. Figure 12 shows that the electrical and exergy efficiency are constant along the length of collector.

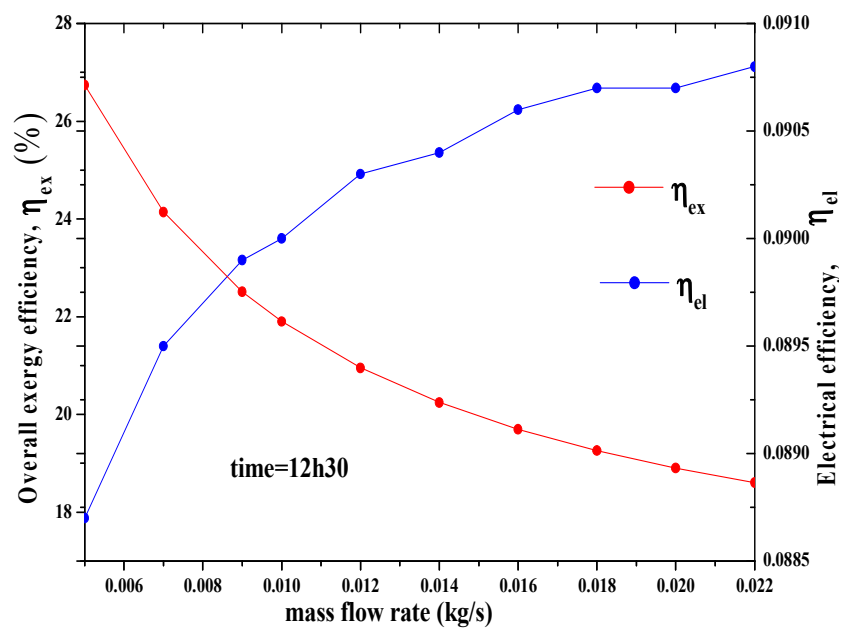

Figure 8. Electrical and overall exergy efficiencies variation with mass flow rate.

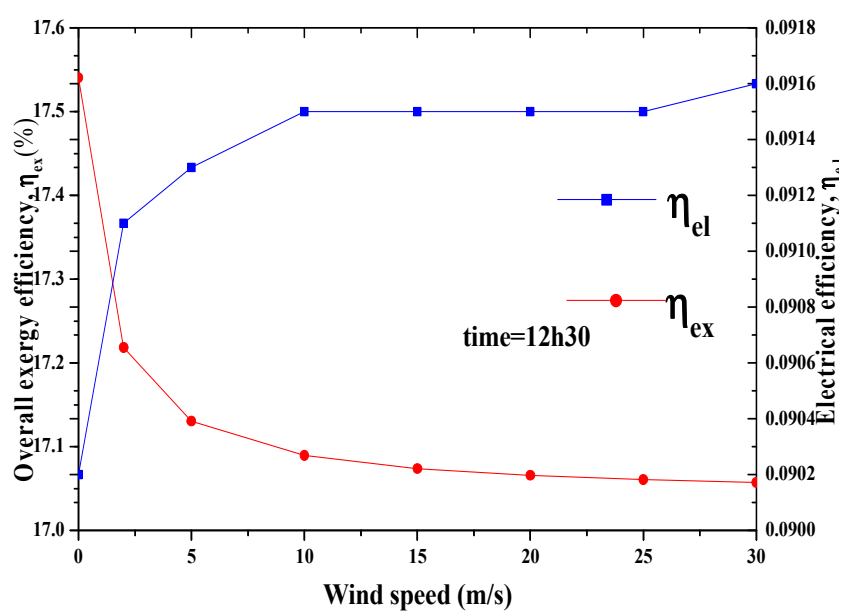

Figure 9. Electrical and overall exergy efficiencies variation with wind speed. 


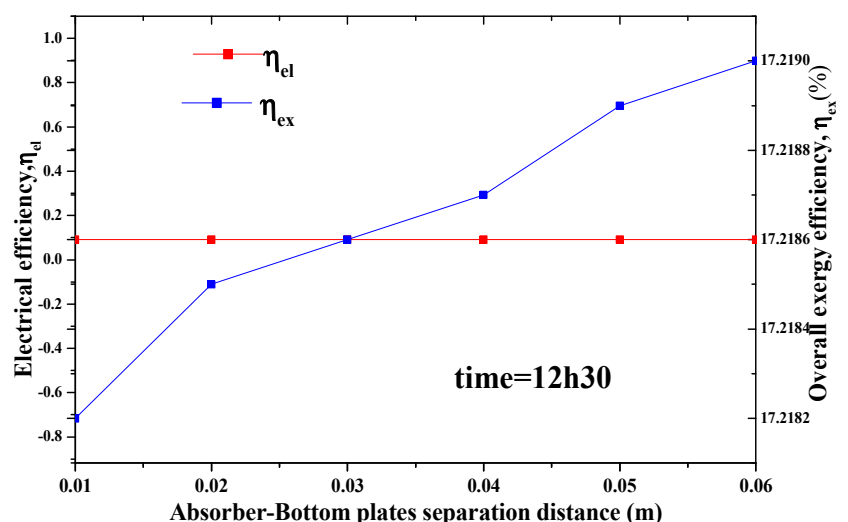

Figure 10. Effect of absorber-bottom plates separation distance on the electrical and overall exergy efficiencies.

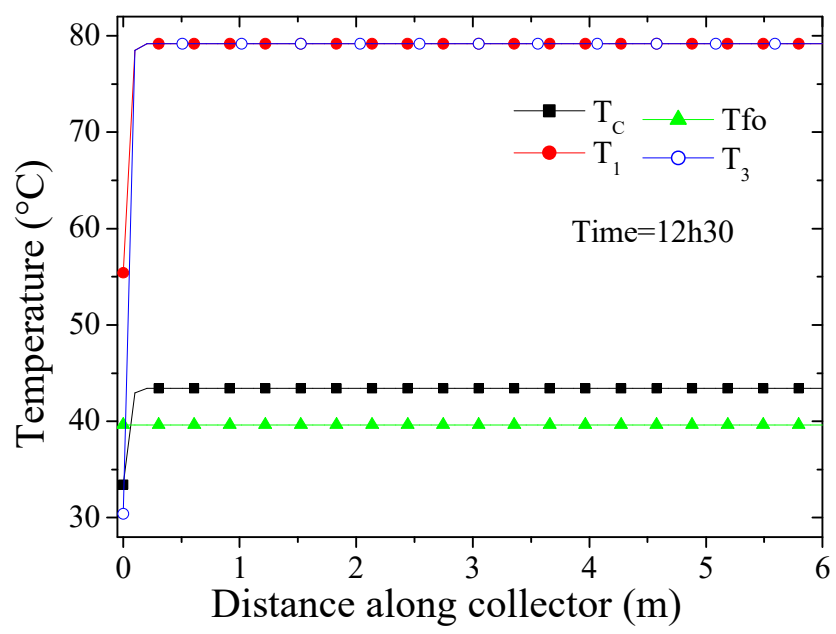

Figure 11. Variation of temperatures along the collector.

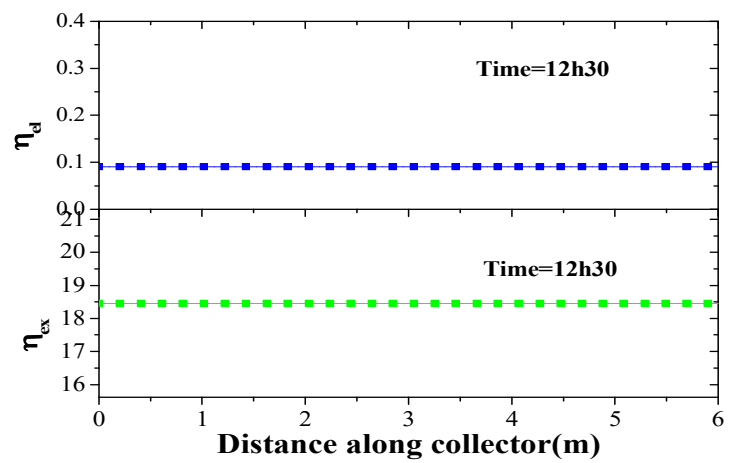

Figure 12. Variation of electrical and overall exergy efficiencies along the collector.

\section{Conclusion}

Hybrid photovoltaic-thermal solar collector with slats was studied in this work. A theoretical solution procedure of the energy equations using a computer code for predicting the electrical and exergy performance of system was used. Solar cells are expected to generate more electricity when they are exposed to higher solar isolation; however their efficiency drops when temperature of the solar cells increases. Result obtained indicated that the electricity production in a $\mathrm{PV} / \mathrm{T}$ hybrid module decreases with increasing panel temperature. At times when electrical performance of the PV panel is lower due to higher absorber plate temperature, corresponding exergy performance is found to be higher. Thus loss in electrical energy is compensated by exergy gain of the system and thus hybrid system becomes very relevant. It is found to be important to use slats as an integral part of the absorber surface in order to achieve better efficiencies. In this case, The instantaneous overall electrical and overall exergy efficiency of a simple pass hybrid (PV/T) solar air heater varies between $9-12 \%$ and $11,5-18,5 \%$ respectively.

\section{Acknowledgements}

All the administration and research members of LISIE and L2SMP labs are grateful acknowledged for their helpful contributions.

\section{Conflict of Interest}

The authors declare no conflict of interest.

\section{Nomenclature}

\begin{tabular}{|c|c|}
\hline A & Area $\left(\mathrm{m}^{2}\right)$ \\
\hline$A_{c}$ & Collector area $\left(\mathrm{m}^{2}\right)$ \\
\hline$C_{p}$ & Specific heat $\left(\mathrm{J} . \mathrm{K}^{-1} \cdot \mathrm{Kg}^{-1}\right)$ \\
\hline $\mathrm{D}_{\mathrm{h}}$ & Hydraulic diameter (m) \\
\hline $\mathrm{F}_{1,2,3,4,5,6}$ & Factor used in the present mathematical models \\
\hline I & Total solar Irradiation $\left(\mathrm{W} / \mathrm{m}^{2}\right)$ \\
\hline $\mathrm{K}$ & Thermal conductivity $\left(\mathrm{W} \cdot \mathrm{m}^{-1} \cdot \mathrm{K}^{-1}\right)$ \\
\hline $\mathrm{K}_{\mathrm{b} 1, \mathrm{~b} 2}$ & Thermal conductivity of insulation $\left(\mathrm{W} \cdot \mathrm{m}^{-1} \cdot \mathrm{K}^{-1}\right)$ \\
\hline $\mathrm{Nu}$ & Nusselt number \\
\hline $\operatorname{Pr}$ & Prandtl number \\
\hline Q & Heat transferred to the air stream (W) \\
\hline $\mathrm{Ra}$ & Raleigh number \\
\hline $\mathrm{Re}$ & Reynolds number \\
\hline$S$ & $\begin{array}{l}\text { Solar radiation absorbed by the absorber surface } \\
\left(\mathrm{W} / \mathrm{m}^{2}\right)\end{array}$ \\
\hline $\mathrm{T}$ & Temperatures $\left({ }^{\circ} \mathrm{C}\right)$ \\
\hline $\mathrm{U}_{\mathrm{b}}$ & Bottom heat loss coefficient $\left(\mathrm{W} / \mathrm{m}^{2} . \mathrm{K}\right)$ \\
\hline $\mathrm{U}_{\mathrm{t}}$ & Top heat loss coefficient $\left(\mathrm{W} / \mathrm{m}^{2} . \mathrm{K}\right)$ \\
\hline $\mathrm{V}$ & Velocity $(\mathrm{m} / \mathrm{s})$ \\
\hline $\mathrm{W}$ & Width (m) \\
\hline $\mathrm{X}_{\mathrm{b} 1, \mathrm{~b} 2}$ & Thickness of insulation (m) \\
\hline $\mathrm{a}, \mathrm{a}_{2}$ & Arbitrary constants \\
\hline$f$ & Friction factor \\
\hline$h$ & Heat transfer coefficient $\left(\mathrm{W} / \mathrm{m}^{2} . \mathrm{K}\right)$ \\
\hline$m$ & Mass flow rate of air $(\mathrm{Kg} / \mathrm{s})$ \\
\hline$n$ & Number of slats, or number of channels \\
\hline$q$ & Heat flux to the air stream $\left(\mathrm{W} / \mathrm{m}^{2}\right)$ \\
\hline $\mathrm{t}$ & Times (s) \\
\hline$w$ & Spacing between slats $(\mathrm{m})$ \\
\hline $\mathrm{y}$ & Distance along collector in flow direction $(\mathrm{m})$ \\
\hline $\mathrm{z}$ & Verticale distance along slat depth (m) \\
\hline
\end{tabular}




\section{Greek Letters}

\begin{tabular}{|c|c|}
\hline$\alpha$ & Absoptivity \\
\hline$\beta$ & Packing factor \\
\hline$\delta$ & Thickness of slats (m) \\
\hline$\rho$ & Masse volumique $\left(\mathrm{Kg} \cdot \mathrm{m}^{-3}\right)$ \\
\hline$\varepsilon$ & Emissivity \\
\hline$\phi$ & Angle $\left(^{\circ}\right)$ \\
\hline$\eta$ & Efficiency \\
\hline$\mu$ & Viscosity $(\mathrm{Kg} / \mathrm{m} . \mathrm{s})$ \\
\hline$\theta$ & Temperature difference $\left({ }^{\circ} \mathrm{C}\right)$ \\
\hline$\sigma$ & Stephan Boltzmann constant $\left(5,67 \times 10^{-8} \mathrm{~W} / \mathrm{m}^{2} \cdot \mathrm{K}^{4}\right)$ \\
\hline$\tau$ & Transmissivity \\
\hline$\Delta y$ & Width space along $y$ axis \\
\hline$\Delta z$ & Width space along $Z$ axis \\
\hline
\end{tabular}

\section{Subscripts}

$\begin{array}{ll}\mathrm{a} & \text { Ambient } \\ \mathrm{b} & \text { Bottom } \\ \mathrm{c} & \text { Convection or Collector or cover } \\ f & \text { Fluid } \\ i & \text { inlet } \\ \mathrm{nc} & \text { Natural convection } \\ \mathrm{O} & \text { outlet } \\ \mathrm{S} & \text { Slats, or sky } \\ u & \text { Usefull } \\ \mathrm{w} & \text { wind } \\ \mathrm{r} & \text { Radiation } \\ \mathrm{el} & \text { Electric } \\ 1 . & \text { Absorber plate } \\ 3 & \text { Bottom plate }\end{array}$

\section{Abbreviations}

$\begin{array}{ll}\text { SPHSAH } & \text { Simple pass hybrid solar air heater } \\ \text { EAHE } & \text { Earth air heat exchanger } \\ \text { PV/T } & \text { Photovoltaic thermal } \\ \text { CGM } & \text { Conjugate gradient method } \\ \text { HTC } & \text { Heat transfer Coefficient } \\ \text { PV } & \text { Photovoltaic }\end{array}$

\section{References}

[1] E. C. Kern Jr. and M. C. Russell, Combined photovoltaic and thermal hybrid collector systems, in: Proc. 13th IEEE photovoltaic specialists Washington, USA. (1978) 1153-1157.

[2] T. Fujisawa, T. Tani, Annual exergy evaluation on photovoltaic-thermal hybrid collector, Sol. Energy. Mat. Sol. c. 47 (1997) 135-148.

[3] T. T. Chow, G. Pei, K. F. Fong, Z. Lin, A. L. S. Chan, J. Li, Energy and Exergy analysis of photovoltaic-thermal collector with and without glass cover, Appl. Energ. 89 (2009) 310-316.

[4] M. Bosonac, B. Sorensen, K. Ivan, H. Sorensen, N. Bruno, B. jamal, photovoltaic/thermal solar collectors and their potential in Denmark, Final report, EFP project (2003).
[5] H. Saitoh, Y. Hamada, H. Kubota, M. Makamura, K. Ochifuji, S. Yokoyama, k. Nagano, Field experiments and analyses on a hybrid solar collector, Appl. Therm. Eng. 23 (2003) 20892105

[6] A. S. Joshi, G. N. Tiwari, Monthly Energy and Exergy analysis of hybrid photovoltaic thermal (PV/T) system for Indian climate, Int. J. Amb. energy. 28 (2) (2007) 99-112.

[7] S. Dubey, G. N. Tiwari, Energy and Exergy analysis of hybrid photovoltaic thermal solar water heater considering with and without with drawl from thank, J. Renew. Sustain. Ener. 2 (2010) 043106.

[8] S. Dubey, S. C. Solanki, G. N. Tiwari, Energy and Exergy analysis of $\mathrm{PV} / \mathrm{T}$ air collectors connected in series, Energ. Buildings. 41 (2009) 863-870.

[9] B. Agrawal and G. N. Tiwari, An energy and exergy analysis of building integrated photovoltaic thermal systems, Energ. source. Part A. 33 (2011) 649-664.

[10] S. Nayak, G. N. Tiwari, Theoretical performance assessment of and integrated photovoltaic and earth air heater exchanger greenhouse using energy and exergy analysis methods, Energ. Buildings 41 (2009) 888-896.

[11] S. Nayak, G. N. Tiwari, Energy and Exergy analysis of photovoltaic/thermal integrated with a solar greenhouse, Energ. Buildings 40 (2008) 2015-2021.

[12] F. Sarhaddi, S. Farahat, H. Ajam, A. Behzadmehr, Exergetic performance assessment of a solar photovoltaic-thermal (PV/T) air collector, Energ. Buildings 4 (2010) 2184-2199.

[13] A. Tiwari, S. Dubey, G. S. Sandhu, M. S. Sodha, S. I. Anwar, Exergy analysis of integrated photovoltaic thermal solar water heater under constant flow rate and constant collection temperature modes, Appl. Energ. 86 (2009) 2592-2597.

[14] V. Raman, G. N. Tiwari, A comparison of Energy and Exergy performance of a hybrid photovoltaic double pass and single pass air collector, Int. J. Agr. Res. Environ. 33 (2009) 605-617.

[15] D. Kamthania, S. Nayak, G. N. Tiwari, Performance evaluation of a hybrid photovoltaic-thermal double pass facade for space heating, Energ. Buildings 43 (2011) 22742281 .

[16] Y. B. Assoa, C. Menezo, G. Fraisse, R. Yezou, J. Baru, Study of a new concept of photovoltaic-thermal hybrid collector, J. Sol. Energ. 81 (2007) 1132-1143.

[17] M. Srinivas, S. Jayaraj, Modeling And Simulation of A Double Pass hybrid -Type (PV/T) Solar Air Heater With Slats, Int. J. Energ. Tech. 4 (2012) 1-10.

[18] M. Srinivas, S. Jayaraj, Energy and Exergy analysis of a two pass photovoltaic-thermal $(\mathrm{PV} / \mathrm{T})$ air heater, Int. J. Energ. Environ. 4 (2013) 467-480.

[19] M. Y. Othman, S. A. Hamid, M. A. S. Tabook, K. Sopian, M. H. Roslan, Z. Ibarahim, Performance analysis of PV/T Combi with water and air heating system: An experimental study, Renew. Energ. 86 (2016) 716-722.

[20] H. Jarimi, M. N. A. Bakar, M. Othman, M. H. Din, Bi-fluid photovoltaic/thermal (PV/T) solar collector: Experimental validation of a 2-D theoretical model, Renew. Energ. 85 (2016) 1052-1067. 
[21] M. N. A. Bakar, M. Othman, M. H. Din, N. A. Manaf, H. Jarimi, Design concept and mathematical model of a bi-fluid photovoltaic/thermal (PV/T) solar collector, Renew. Energ. 67 (2014) 153-164.

[22] O. K. Ahmed, Z. A. Mohammed, Dust effect on the performance of the hybrid PV/Thermal collector, Therm. Sci. Eng. Prog. 3 (2017) 114-122.

[23] O. K. Ahmed, Z. A. Mohammed, Experimental investigation of PV/thermal collector with theoretical analysis, Renew. Energ. Focus 27 (2018) 67-77.

[24] F. Sobhnamayan, F. Sarhaddi, M. A. Alavi, S. Farahat, J. Yazdanpanahi, Optimization of a solar photovoltaic thermal $(\mathrm{PV} / \mathrm{T})$ water collector based on exergy concept, Renew. Energ. 68 (2014) 356-365.

[25] M. Jee Joe, S. Iniyan, G. Ranko, Flat plate solar photovoltaicthermal (PV/T) systems: A reference guide, Renew. Sustain. Energ. Rev. 51 (2015) 62-88.

[26] K. S. ONG, Thermal Performance of Solar Air Heaters:
Mathematical Model and Solution Procedure, Sol. Energ. 55 (1995) 93-109.

[27] H. D. Ammari, A mathematical model of thermal performance of a solar air heater with slats, Renew. Energ. 28 (2002) 1597 1615 .

[28] K. G. T. Holland, T. E. Unny, G. R. Raithby, L. Konicek, Free convective heat transfer across inclined air layers, Trans. ASME. J. Heat transfer. 98 (1976)189-193.

[29] H. S. Heaton, W. C. Reynolds, W. M. Kay, Heat transfer in annular passages, simultaneous development of velocity and temperature fields in laminar flow, Int. J. Heat Mass Transfer. 7 (1964) 763.

[30] Kays WM, Crawford ME. Convective Heat and Mass transfer, 3 third ed., New York, Mc Graw-Hill, 1993.

[31] B. S. Petukho, heat transfer and Friction in Turbulent Pipe Flow with variable physical properties. In: J. P. Hartnett, T. F. Irvine (Eds), Advances in Heat Transfer, Academic press, New York, 1970, pp. 504-564. 